\title{
Efektifitas Jus Nanas terhadap Keputihan (Fluor albus) pada Wanita Usia Subur (WUS)
}

\author{
Sofia Mawaddah \\ Jurusan Kebidanan, Politeknik Kesehatan Kemenkes Palangka Raya, Indonesia \\ Email: sofizline@gmail.com
}

\begin{abstract}
Effectiveness of Pineapple Juice on Leucorrhoea (Fluor albus) in Fertile Age Women (WUS). The mechanism of action of inhibition of pineapple extract against Staphylococcus aureus is a bromelain enzyme which is a proteolytic enzyme that plays a role in protein breakdown. The workings of the bromelain enzyme that inhibits the bacterium Staphylococcus aureus is to reduce the surface tension of the bacteria by hydrolyzing proteins and glycoproteins. This study also found that pineapple extract concentration of $70 \%$ is an effective concentration in inhibiting the growth of bacteria that cause vaginal discharge. The purpose of this study was to determine the effectiveness of pineapple juice against leucorrhoea (Fluor albus) in women of childbearing age (WUS) in the Pahandut Seberang district of Palangkaraya City. The research method used was the Quasy Experiment with the Pretest and Postest Nonequivalent Control Group design. The sample in this study amounted to 70 divided into 2 groups: 35 mothers were given pineapple juice and 35 mothers were given vaginal discharge. The sampling technique used is non-random with data analysis using the Man-Whitney test. Statistical test results with the Man-Whitney test showed that the p-value $=0,000$ ( $\mathrm{p}$-value $<0,05)$ which showed that there was an influence of giving pineapple juice on vaginal discharge in women of childbearing age in the Pahandut Seberang Kelurahan of Palangka Raya.
\end{abstract}

Keywords: Fluor albus, Pineapple juice, Women of childbearing age

\begin{abstract}
Abstrak: Efektifitas Jus Nanas terhadap Keputihan (Fluor albus) pada Wanita Usia Subur (WUS). Mekanisme kerja daya hambat ekstrak nanas terhadap bakteri Staphylococcus aureus adalah enzim bromelin yang merupakan suatu enzim proteolitik yang berperan dalam pemecahkan protein. Cara kerja enzim bromelin yang menghambat bakteri Staphylococcus aureus adalah menurunkan tegangan permukaan bakteri dengan cara menghidrolisis protein dan gliko protein. Pada penelitian ini juga didapatkan bahwa esktrak nanas konsentrasi $70 \%$ merupakan konsentrasi yang efektifitas dalam menghambat pertumbuhan bakteri yang menyebabkan keputihan. Tujuan penelitian mengetahui efektifitas jus nanas terhadap keputihan (Fluor albus) pada wanita usia subur (WUS) di wilayah kelurahan Pahandut Seberang Kota Palangka Raya. Metode penelitian yang digunakan adalah quasy eksperiment dengan desain pre-test and post-test nonequivalent control group. Sampel pada penelitian ini berjumlah 70 dibagi menjadi 2 kelompok yaitu $35 \mathrm{ibu}$ diberikan jus nanas dan $35 \mathrm{ibu}$ diberikan obat keputihan. Teknik sampling yang digunakan yaitu non random dengan analisis data menggunakan uji Man-Whitney. Hasil uji statistik dengan uji Man-Whitney menunjukkan bahwa nilai $p$-value $=0,000$ ( $p$-value $<0,05)$ yang menunjukkan bahwa ada pengaruh pemberian jus nanais terhadap keputihan pada wanita usia subur di Kelurahan Pahandut Seberang kota Palangka Raya.
\end{abstract}

Kata kunci: Fluor albus, Jus nanas, Wanita usia subur

\section{PENDAHULUAN}

Kesehatan yang terjaga berawal dari menjaga kebersihan. Kesehatan reproduksi merupakan unsur terpenting dalam kesehatan umum, baik pada perempuan ataupun pada lakilaki, kesehatan reproduksi juga dapat mempengaruhi kesehatan bayi, anak, remaja dan orang yang berusia di luar masa reproduksi. Hal ini juga berlaku bagi kesehatan organ seksual, termasuk vagina. Vagina merupakan salah satu organ reproduksi wanita yang sangat rentan terkena penyakit infeksi, salah satunya adalah keputihan (Rahmawati, 2017; Janah, 2013).

Menurut World Health Organization
(WHO) masalah kesehatan reproduksi perempuan yang buruk mencapai 33\% dari total beban penyakit yang diderita para perempuan di 
dunia salah satunya adalah keputihan (Putranto, 2016 dalam Rismawan, 2017).

Keputihan (Leukore/Fluor albus) merupakan cairan yang keluar dari vagina. Masalah keputihan adalah masalah yang sejak lama menjadi persoalan bagi kaum wanita. Data menunjukkan $75 \%$ wanita di dunia pasti menderita keputihan, paling tidak sekali seumur hidup dan $45 \%$ diantaranya dapat mengalami dua kali atau lebih (G.A. Marhaeni, 2017).

Menurut Wijayanti (2009), keputihan fisiologis terdiri atas cairan yang kadang-kadang berupa mukus yang mengandung banyak epitel dengan leukosit yang jarang. Keputihan normal ciri-cirinya seperti berwarna kuning, kadangkadang putih kental, tidak berbau tanpa disertai rasa nyeri, gatal, rasa terbakar. Keputihan keluar pada saat menjelang menstruasi dan sesudah menstruasi atau pada saat stres dan kelelahan.

Keputihan yang tidak normal ialah keputihan dengan ciri-ciri: jumlahnya banyak, timbul terus menerus, warnanya berubah (misalnya kuning, hijau, abu-abu, menyerupai susu/yoghurt) disertai adanya keluhan seperti gatal, panas, nyeri serta berbau apek dan amis. Keputihan yang disebabkan oleh infeksi biasanya disertai dengan rasa gatal di dalam vagina dan di sekitar bibir vagina bagian luar. Yang sering menimbulkan keputihan ini antara lain bakteri, virus, jamur, atau juga parasit. Infeksi ini dapat menjalar dan menimbulkan peradangan ke saluran kencing, sehingga menimbulkan rasa pedih saat si penderita buang air kencing. Pada tahapan komplikasi, keputihan sendiri dapat menimbulkan masalah kesehatan yang lebih serius seperti infertilitas, penyakit radang panggul, infeksi saluran telur, bahkan awal timbulnya pertumbuhan kanker mulut rahim (Ellya, dkk., 2010).

Menurut WHO, berdasarkan data statistik di Indonesia tahun 2008, dari 43,3 juta jiwa, remaja yang berusia 15-24 tahun memiliki perilaku tidak sehat, seperti penggunaan cairan pembersih vagina, celana ketat, personal hygiene, dan pemakaian panty liner (Azizah dan Widiawati, 2015). Bahkan $75 \%$ perempuan pernah mengalami keputihan minimal satu kali dalam hidupnya dan $45 \%$ diantaranya mengalami keputihan sebanyak 2 kali atau lebih (BKKBN, 2009).

Saat ini telah banyak dikembangkan anti bakteri dengan bahan dasar tumbuhan yang diyakini mempunyai khasiat antibakteri dengan efek samping minimal, salah satunya adalah nanas. Buah nanas (Ananassativus) adalah sejenis tumbuhan tropis yang berasal dari negara Brazil, Bolivia dan Paraguay. Buah nanas mengandung banyak vitamin, nutrisi dan gizi yang terkandung di dalam buah nanas diantaranya seperti vitamin $\mathrm{C}$, manganese dan asam folat. Buah nanas juga mengandung senyawa bromelain yang dapat memberikan manfaat kesehatan bagi yang mengkonsumsinya. Manfaat lain dari buah nanas yaitu meningkatkan sistem kekebalan tubuh, mencegah penyakit kanker, penyembuhan luka, meningkatkan kesehatan pada usus, asupan gizi yang baik bagi wanita dan dapat mengurangi keputihan.

Penelitian sebelumnya yang telah dilakukan mengenai uji daya antibakteri dari ektrak buah nanas antara lain Suerni, et al. (2013), melakukan uji daya hambat ekstrak buah nanas, salak dan kweni terhadap bakteri Staphylococcus aureus yang menunjukkan ekstrak buah nanas dapat menghambat pertumbuhan bakteri Staphylococcus aureus dengan konsentrasi 50 dan $100 \%$.

Buah nanas dapat dikonsumsi menjadi jus untuk mengurangi keputihan dan dikonsumsi secara teratur 1 kali sehari selama 2 minggu dangan 100gram daging buah nanas dan bonggolnya dengan ditambahkan air 50ml. Buah nanas dapat dikonsumsi secara langsung dengan membuang kulitnya dan dicuci bersih dengan air mengalir. Mekanisme kerja daya hambat ekstrak buah nanas terhadap bakteri Staphylococcus Aureus. Cara kerja Enzim bromelin adalah menurunkan tegangan permukaan bakteri dengan cara menghidrolisis protein dan Glikoprotein. Ekstrak buah nanas pada dosis $1000 \mathrm{ug} / \mathrm{ml}$ sebesar $23 \mathrm{~mm}$ pada bakteri Staphylococcus aureus.

Tujuan penelitian untuk mengetahui efektifitas jus nanas terhadap keputihan (Fluor albus) pada wanita usia subur (WUS) di wilayah kelurahan pahandut Kota Palangka Raya.

\section{METODE}

Penelitian ini menggunakan quasy eksperiment dengan desain pre-test and pro-test non-equivalent control group. Penelitian ini dilakukan di wilayah Kelurahan Pahandut Seberang Kota Palangka Raya pada bulan Januari-Februari 2019. Populasi dalam penelitian ini adalah seluruh wanita usia subur yang mengalami keputihan di RW 01 Pahandut Seberang Palangka Raya dengan jumlah sampel 70 wanita usia subur yang dibagi menjadi 2 kelompok yaitu 35 kelompok pre-test dan 35 kelompok post-test. Teknik pengambilan sampel yaitu purposive sampling dengan memilih sampel yang memenuhi kriteria inklusi. Jenis data di penelitian ini yaitu data primer. Peneliti 
melalukan pemeriksaan in spekulo untuk mengetahui sifat keputihan normal atau tidak normal.

Analisis yang digunakan dalam penelitian ini adalah analisis univariat untuk mengetahui nilai rata-rata distribusi frekuensi masing-masing variabel dan analisis bivariat dalam penelitian ini yaitu untuk mengetahui pengaruh jus nanas terhadap keputihan dengan menggunakan uji dependen T-test. Penelitian telah di uji etik dan disetujui oleh Komisi Etik Penelitian Kesehatan Poltekkes Kemenkes Palangka Raya dengan Nomor:089 B/II/KE.PE/2019.

\section{HASIL}

Tabel 1. Karakteristik Penelitan

\begin{tabular}{lcc}
\hline \multicolumn{1}{c}{ Variabel } & Frekuensi & $\%$ \\
\hline Pengetahuan & & \\
\hline Baik & 22 & 31,4 \\
Kurang & 48 & 68,6 \\
\hline Personal Hygiene & & \\
\hline Baik & 19 & 27,1 \\
Kurang & 51 & 72,9 \\
\hline
\end{tabular}

Berdasarkan tabel 1, pengetahuan wanita usia subur yang baik ada 22 responden $(31,5 \%)$ dan pengetahuan wanita usia subur yang kurang ada 48 responden $(68,8 \%)$. Personal hygiene yang baik ada 19 responden $(27,1 \%)$ dan personal hygiene yang kurang ada 51 responden $(72,9 \%)$.

Tabel 2. Distribusi Frekuensi Keputihan Pada Wanita Usia Subur Sebelum dan Sesudah Pemberian Jus Nanas

\begin{tabular}{lcc}
\hline \multicolumn{1}{c}{ Sebelum diberikan jus nanas } & f & $\mathbf{\%}$ \\
\hline Normal & 15 & 42,9 \\
Tidak Normal & 20 & 57,1 \\
\hline Sesudah diberikan jus nanas & & \\
\hline Normal & 20 & 57,1 \\
Tidak Normal & 15 & 42,9 \\
\hline
\end{tabular}

Berdasarkan tabel 2, sebelum diberikan jus nanas ada 15 responden (42,9\%) mengalami keputihan normal dan 20 responden $(57,1 \%)$ mengalami keputihan tidak normal. Sesudah diberikan jus nanas ada 20 responden $(57,1 \%)$ mengalami keputihan normal dan ada ada 15 responden $(42,9 \%)$ mengalami keputihan tidak normal.
Tabel 3. Distribusi Frekuensi Keputihan Pada Wanita Usia Subur Sebelum dan Sesudah Pemberian Obat

\begin{tabular}{lcc}
\hline \multicolumn{1}{c}{ Sebelum diberikan obat } & f & \% \\
\hline Normal & 21 & 60,0 \\
Tidak Normal & 14 & 40,0 \\
\hline Sesudah diberikan obat & & \\
\hline Normal & 19 & 54,2 \\
Tidak Normal & 16 & 45,7 \\
\hline
\end{tabular}

Berdasarkan tabel 3, sebelum diberikan obat ada 21 responden (60\%) mengalami keputihan normal dan 14 responden (40\%) mengalami keputihan tidak normal. Sesudah diberikan obat ada 19 responden $(54,2 \%)$ mengalami keputihan normal dan ada 16 responden $(45,7 \%)$ mengalami keputihan tidak normal.

Tabel 4. Analisis Pengaruh Jus Nanas terhadap Keputihan pada Wanita Usia Subur

\begin{tabular}{cccc}
\hline \multirow{2}{*}{ Jus nanas } & \multicolumn{2}{c}{ Keputihan } & $\boldsymbol{p}$ - \\
\cline { 2 - 3 } & SD & Mean & value \\
\hline Sebelum diberikan & 0,502 & 2,57 & 0,000 \\
Sesudah diberikan & 0,507 & 1,51 & \\
\hline
\end{tabular}

Berdasarkan tabel 4, standar deviasi sebelum diberikan jus nanas 0,502 dengan ratarata 2,57 dan standar deviasi sesudah diberikan jus nanas 0,507 dengan rata-rata 1,51. Di peroleh nilai $p$-value nya yaitu 0,000 yang menunjukkan ada pengaruh sebelum dan sesudah pemberian jus nanas terhadap keputihan pada wanita usia subur.

\begin{tabular}{lcrc}
$\begin{array}{c}\text { Tabel 5. Analisis Pengaruh Obat Keputihan } \\
\text { Terhadap Keputihan pada Wanita } \\
\text { Usia Subur }\end{array}$ & \\
\cline { 2 - 3 } & \multicolumn{2}{c}{ Keputihan } & $\begin{array}{c}\boldsymbol{p} \text { - } \\
\text { value }\end{array}$ \\
\cline { 2 - 3 } Obat Keputihan & SD & Mean & \\
\hline Sebelum diberikan & 0,512 & 2,60 & 0,003 \\
Sesudah diberikan & 0,515 & 1,71 & \\
\hline
\end{tabular}

Berdasarkan tabel 5, standar deviasi sebelum diberikan obat keputihan 0,512 dengan rata-rata 2,60 dan standar deviasi sesudah diberikan obat keputihan 0,515 dengan rata-rata 1,71. Di peroleh nilai $p$-value nya yaitu 0,003 yang menunjukkan ada pengaruh sebelum dan sesudah pemberian jus nanas terhadap keputihan pada wanita usia subur. 
Tabel 6. Efektifitas Jus Nanas terhadap Keputihan pada Wanita Usia Subur

\begin{tabular}{lccc}
\hline \multicolumn{1}{c}{ Variabel } & SD & Mean & $\begin{array}{c}\boldsymbol{p} \text { - } \\
\text { value }\end{array}$ \\
\hline Jus Nanas & & & \\
Keputihan normal & 0,502 & 2,57 & 0,000 \\
Keputihan tidak normal & 0,507 & 1,51 & \\
\hline Obat Keputihan & & & \\
Keputihan normal & 0,512 & 2,60 & 0,003 \\
Keputihan tidak normal & 0,515 & 1,71 & \\
\hline
\end{tabular}

Pada tabel 6, di peroleh nilai p-value pemberian jus nanas 0,000 sedangkan pemberian obat keputihan yaitu 0,003 yang menunjukkan bahwa jus nanas juga efektif untuk mengurangi keputihan pada wanita usia subur.

\section{PEMBAHASAN}

Pada tabel 1 distribusi frekuensi wanita usia subur yang mengalami keputihan berdasarkan pengetahuan di wilayah Kelurahan Pahandut Seberang Palangka Raya adalah pengetahuan kurang sebanyak 48 responden $(68,6 \%)$, dan pengetahuan baik sebanyak 22 responden $(31,4 \%)$. Pada penelitian ini bahwa kasus terbanyak wanita usia subur yang mengalami keputihan adalah wanita usia subur dengan pengetahuan kurang yang mengalami keputihan ringan sebanyak 29 responden $(60,4 \%)$, sedangkan wanita usia subur yang mengalami keputihan berat dengan perilaku kurang sebanyak 19 responden $(39,6 \%)$.

Pengetahuan pada hakikatnya merupakan apa yang diketahui tentang suatu objek tertentu dan setiap jenis pengetahuan mempunyai ciri-ciri spesifik mengenai apa (ontology), bagaimana (epistemology) dan untuk apa (aksiology) pengetahuan tersebut (Notoatmodjo, 2010). Pengetahuan yang masih rendah tentang keputihan, karena kurangnya informasi yang didapatkan oleh kalangan wanita usia subur, akses pelayanan kesehatan yang kurang memadai dan cara perawatan organ reproduksi wanita yang kurang baik (Sandriana, 2014).

Penelitian ini didukung dengan penelitian yang telah dilakukan oleh Mokodongan (2015) bahwa pengetahuan adalah salah satu faktor terbentuknya perilaku, yaitu faktor yang memotivasi. Faktor ini berasal dari dalam diri seseorang yang menjadi alasan atau motivasi untuk melakukan suatu perilaku. Pentingnya mengetahui tentang keputihan adalah agar wanita mengetahui tentang keputihan, tanda dan gejala keputihan, penyebab, dan dapat membedakan antara keputihan fisiologis dan patologis sehingga wanita dapat mencegah, menangani dan segera melakukan pemeriksaan apabila terdapat tanda dan gejala keputihan yang tidak normal.

Pada tabel 1 juga diperoleh wanita usia subur yang mengalami keputihan berdasarkan personal hygiene di wilayah Kelurahan Pahandut Seberang Palangka Raya adalah personal hygiene kurang sebanyak 50 responden $(98,6 \%)$, dan personal hygiene baik sebanyak 20 responden $(27,1 \%)$. Pada penelitian ini bahwa kasus terbanyak wanita usia subur yang mengalami keputihan adalah wanita usia subur dengan personal hygiene kurang yang mengalami keputihan ringan sebanyak 31 responden $(60,8 \%)$, sedangkan wanita usia subur yang mengalami keputihan berat dengan personal hygiene kurang sebanyak 20 responden $(39,2 \%)$.

Personal hygiene adalah suatu tindakan untuk memelihara kebersihan dan kesehatan seseorang untuk kesejahteraan fisik dan psikis. apabila ingin terhindar dari keputihan maka harus menjaga kebersihan daerah genitalia. Personal hygiene yang kurang baik seperti menggunakan jamban yang kotor sehingga untuk membasuh organ intim menggunakan air sungai, menggunakan pakaian dalam yang sangat ketat, melakukan cara pembilasan vagina dengan arah yang salah, umumnya melakukan dari arah anus ke arah vagina, yang benar adalah dari vagina ke arah anus, melakukan pertukaran pemakaian handuk dengan orang lain, mengalami stres dan kelelahan, tidak sering mengganti pembalut saat menstruasi, sering menggaruk-garuk pada daerah organ intim, tinggal dilingkungan yang kotor, dan memakai pantyliner yang tidak berkualitas atau terbuat dari bahan daur ulang dan mengandung pemutih, cebok tidak bersih, celana dalam yang lembab akan menimbulkan tumbuhnya jamur, yang merupakan penyebab Fluor Albus (Riza, dkk., 2019).

Keputihan yang terjadi tersebut cenderung disebabkan oleh masih minimnya kesadaran untuk menjaga kesehatan terutama kesehatan organ genitalianya. Selain itu, keputihan sering dikaitkan dengan kadar keasaman daerah sekitar vagina, bisa terjadi akibat $\mathrm{pH}$ vagina tidak seimbang. Sementara kadar keasaman vagina disebabkan oleh dua hal yaitu faktor internal dan faktor eksternal. Faktor eksternal antara lain kurangnya personal hygiene, pakaian dalam yang ketat, dan penggunaan WC umum yang tercemar bakteri Clamydia. Selain itu penyebab keputihan juga karena perilaku atau kebiasaan seseorang yang tidak memperhatikan kebersihan organ reproduksinya, yang sering disebut personal hygiene.

Personal hygiene yang kurang baik menandakan bahwa kurangnya memperoleh 
pengetahuan mengenai personal hygiene sehingga pengetahuan tersebut mempengaruhi perilaku, dimana penerimaan perilaku baru didasari oleh pengetahuan, kesadaran dan sikap positif, maka prilaku tersebut akan bersifat langgeng (long lasting). Sebaliknya apabila perilaku tidak didasari oleh pengetahuan dan kesadaran maka tidak akan berlangsung lama.

Penelitian ini sependapat dengan penelitian yang telah dilakukan oleh Yuliasari (2015) menunjukkan bahwa pada remaja putri di Risma Miftahulhuda Kabupaten Lampung Selatan Tahun 2015 sebagian besar mengalami keputihan yang normal atau biasa yang dialami oleh remaja putri pada umumnya. Namun untuk remaja putri dengan personal hygiene yang kurang baik memiliki persentase yang cukup besar, yang mengalami keputihan abnormal yaitu sebesar 42 remaja putri (40\%), sedangkan untuk remaja putri dengan personal hygiene yang baik hanya sebanyak 2 remaja putri $(4,9 \%)$. Keadaan tersebut menunjukkan bahwa terdapat hubungan yang bermakna antara personal hygiene dengan kejadian keputihan yang abnormal pada remaja putri di Risma Miftahulhuda Kabupaten Lampung Selatan. Hal ini juga diperkirakan disebabkan oleh kurangnya informasi yang mereka dapatkan mengenai personal hygiene khususnya pada organ reproduksinya.

Penelitian ini didukung dengan penelitian yang telah dilakukan oleh Irnawati (2017) bahwa penyebab keputihan yaitu salah satunya adalah dari personal hygiene seperti air cebok tidak bersih dan cara ceboknya yang salah. Semakin banyak yang personal hygiene organ reproduksinya kurang baik maka semakin banyak yang personal hygiene organ reproduksinya buruk, karena banyak wanita usia subur yang cara ceboknya salah dan air ceboknya tidak bersih. Oleh karena itu perlu mengetahui berbagai macam cara untuk melakukan personal hygiene yang benar.

Pada tabel 2 diperoleh, sebelum diberikan jus nanas ada 15 responden $(42,9 \%)$ mengalami keputihan normal dan 20 responden $(57,1 \%)$ mengalami keputihan tidak normal. Sesudah diberikan jus nanas ada 20 responden $(57,1 \%)$ mengalami keputihan normal dan ada ada 15 responden $(42,9 \%)$ mengalami keputihan tidak normal.

Pada tabel 3, sebelum diberikan obat ada 21 responden (60\%) mengalami keputihan normal dan 14 responden (40\%) mengalami keputihan tidak normal. Sesudah diberikan obat ada 19 responden $(54,2 \%)$ mengalami keputihan normal dan ada 16 responden $(45,7 \%)$ mengalami keputihan tidak normal.
Keputihan atau Fluor albus adalah kondisi vagina saat mengeluarkan cairan atau lendir menyerupai nanah yang disebabkan oleh kuman. Terkadang, keputihan dapat menimbulkan rasa gatal, bau tidak enak, dan berwarna hijau (Prayitno, 2010:45).

Keputihan dikalangan medis dikenal dengan istilah leukore atau fluor albus, yaitu keluarnya cairan dari vagina yang terjadi karena infeksi jamur kandida pada genitalia perempuan disebabkan oleh organisme seperti ragi yaitu candida albicans. Dalam keadaan normal, vagina memproduksi cairan yang berwarna bening, tidak berbau, tidak berwarna, jumlahnya tidak berlebihan dan tidak disertai gatal. Keputihan dapat terjadi pada keadaan yang normal (fisiologis), namun dapat juga merupakan gejala dari suatu kelainan yang harus diobati (patologis) (Johar, dkk., 2013).

Flour albus yang normal adalah cairan dari vagina sesudah mendapat haid yang pertama, dari kelenjar yang terdapat pada cervix yang menimbulkan lendir karena pengaruh hormon estrogen, dan jumlah yang keluar berubah-ubah sesuai dengan siklus haid, terdiri dari cairan yang kadang berupa muсus yang mengandung banyak epitel dan leukosit yang jarang, wanita dewasa apabila mendapat rangsangan, dan waktu koitus atau sekitar ovulasi sekitar ovulasi. Fluor albus yang abnormal menimbulkan rasa gatal, nyeri didalam vagina atau sekeliling saluran pembuka vulva.

Umumnya dipicu kuman penyakit (pathogen) dan menyebabkan infeksi. Akibat timbulnya gejala yang sangat mengganggu, sepertinya berubah warna cairan menjadi kekuningan hingga kehijauan, jumlah berlebih dan berbau serta menimbulkan rasa gatal di daerah sekitar vagina (Wulaningtyas, et all., 2018).

Penyebab paling penting dari keputihan ialah infeksi. Keputihan yang disebabkan oleh infeksi biasanya disertai dengan rasa gatal di dalam vagina dan di sekitar bibir vagina bagian luar. Yang sering menimbulkan keputihan ini antara lain bakteri, virus, jamur, atau juga parasit. Infeksi ini dapat menjalar dan menimbulkan peradangan ke saluran kencing, sehingga menimbulkan rasa pedih saat si penderita buang air kencing (Wijayanti, 2009).

Nanas (Ananassativus) adalah sejenis tumbuhan tropis yang berasal dari Brazil, Bolivia dan Paraguay. Tumbuhan ini termasuk dalam familia nanas-nanasan (Famili Bromeliaceae). Nanas (Ananas comosus L.merr) yaitu tanaman tropis yang merupakan keluarga dari bromeliaceae, pada bidang medis telah digunakan 
karena memiliki kandungan enzim kompleks yang dapat mengobati berbagai kondisi patologis. Daun, buah, bonggol, batang, dan akar nanas mengandung enzim bromelain, saponin, flavonoid, dan tanin (Rakhmanda, 2008; Nurhidayah dkk., 2013).

Penelitian ini sejalan dengan penelitian yang dilakukan oleh Rakhmanda (2018) bahwa nanas merupakan buah yang mempunyai kandungan sangat kompleks, kaya akan mineral baik makro maupun mikro, zat organik, air, dan juga vitamin. Kandungan klor, iodium, fenol dan bromelin pada nanas mempunyai efek menekan pertumbuhan bakteri. Nanas (Ananas comosus L.merr) mempunyai efek sebagai anti bakteri, baik menghambat (bakteriostatic) maupun membunuh (bactericidal). Konsentrasi minimal jus nanas yang masih dapat menghambat bakteri adalah $25 \%$, sedangkan pada konsentrasi $100 \%$ jus nanas mempunyai efek membunuh bakteri pada kasus keputihan. Semakin tinggi konsentrasinya, semakin besar efek anti bakteri dari jus nanas. Nanas juga mengandung enzim bromelin yang dapat digunakan sebagai antiseptic. Cara kerja enzim bromelin adalah menurunkan tegangan permukaan bakteri dengan cara menghidrolisis bakteri-bakteri yang merupakan mediator bakteri melekat pada organorang vagina yang menyebabkan keputihan.

Menurut penelitian Umarudin, et al (2018) bahwa pemanfaatan enzim bromelin dimanfaatkan sebagai antibiotik, antibakteri, antiinflamasi, antitumor, dan antikanker. Selain itu juga mengobati penyakit patologis. Ekstrak buah nanas mampu menghambat pertumbuhan bakteri Staphylococcus aureus. Hal ini menunjukan bahwa berpengaruh positif dalam menghambat dan membunuh bakteri Staphylococcus aureus (bakterisid).

Pada tabel 4 diperoleh standar deviasi sebelum diberikan jus nanas 0,502 dengan ratarata 2,57 dan standar deviasi sesudah diberikan jus nanas 0,507 dengan rata-rata 1,51. Di peroleh nilai $p$-value yaitu 0,000 yang menunjukkan ada pengaruh sebelum dan sesudah pemberian jus nanas terhadap keputihan pada wanita usia subur.

Pada penelitian ini peneliti mendapatkan hasil pada wanita usia subur yang mengonsumsi jus nanas selama 1 minggu secara teratur dapat mengurangi keputihan, sedangkan pada wanita usia subur yang mengonsumsi jus nanas pada pagi hari sebelum makan dan mengonsumsi obat 2 jam setelah makan secara teratur setiap hari akan mengurangi keputihan selama kurang lebih 3 hari.
Hasil penelitian ini sejalan dengan penelitian Rakhmanda (2018) bahwa nanas merupakan buah yang mempunyai kandungan sangat kompleks, mempunyai efek sebagai anti bakteri, baik menghambat (bakteriostatic) maupun membunuh (bactericidal).

Pada buah nanas memiliki senyawa flavonoid yang bersifat desinfektan dan sangat efektif dalam menghambat pertumbuhan bakteri gram positif karena flavonoid bersifat polar sehingga lebih mudah menembus lapisan peptidoglikan dan juga bersifat polar pada bakteri gram positif daripada lapisan lipid yang non polar. Setelah masuk, flavonoid segera bekerja menghancurkan bakteri dengan cara mendenaturasi protein yang dapat menyebabkan aktifitas metabolism. Sel bakteri berhenti karena semua aktivitas metabolism sel bakteri dikatalisis oleh suatu enzim yang merupakan protein. Berhentinya antivitas metabolisme ini akan mengakibatkan kematian sel bakteri.

Pada Penelitian yang dilakukan oleh Loon, et al (2018) ekstrak nanas memiliki efek antibakteri terhadap Staphylococcus aureus karena bromelain sebagai senyawa aktif, dan faktor-faktor fitokimia seperti vitamin $\mathrm{C}$ dan flavonoid. Sejalan pula dengan penelitian Rahkmanda (2008) yang memperlihatkan peningkatan efek antibakteri dari konsentrasi $25 \%$ dan $50 \%$ jus nanas dalam menghambat pertumbuhan bakteri $S$. mutans dan pada konsentrasi $100 \%$ jus nanas dapat membunuh bakteri $S$. mutans.

\section{SIMPULAN}

Dari hasil penelitian diketahui, bahwa jus buah nanas terbukti mampu mengurangi keputihan pada wanita usia subur karena Pada buah nanas memiliki senyawa flavonoid yang bersifat desinfektan dan sangat efektif dalam menghambat pertumbuhan bakteri gram positif karena flavonoid bersifat polar sehingga lebih mudah menembus lapisan peptidoglikan dan juga bersifat polar pada bakteri gram positif daripada lapisan lipid yang non polar. Setelah masuk, flavonoid segera bekerja menghancurkan bakteri dengan cara mendenaturasi protein yang dapat menyebabkan aktifitas metabolisme. Sel bakteri berhenti karena semua aktivitas metabolisme sel bakteri dikatalisis oleh suatu enzim yang merupakan protein. Berhentinya antivitas metabolisme ini akan mengakibatkan kematian sel bakteri. 


\section{DAFTAR PUSTAKA}

Azizah, N., dan Widiawati, I. (2015). Karakteristik Remaja Putri dengan Kejadian Keputihan di SMK Muhammadiyah Kudus. Jurnal Ilmiah Kesehatan (JIK), 6(1), 57-58.

BKKBN. (2009). Survei Kesehatan Reproduksi Remaja Indonesia. Jakarta: Badan Pusat Statistik Indonesia.

Ellya, Eva, dkk. (2010). Kesehatan Reproduksi Wanita. Jakarta: CV Trans Info Media.

G. A. Marhaeni. (2017). Keputihan pada Wanita. J. Skala Husada J. Heal.

Irnawati, Y., \& Setyaningrum, V. N. (2017). Hubungan Personal Hygiene Organ Reproduksi dengan Kejadian Keputihan pada Remaja Siswi SMK N 1 Sumber Kecamatan Sumber Kabupaten Rembang. URECOL, 47-52.

Janah, A. F., Ridwan, E. S., \& Wahyuningsih, W. (2013). Perilaku Vulva Hygiene Berhubungan dengan Kejadian Keputihan pada Remaja Putri Kelas XII SMA GAMA 3 Maret Yogyakarta. Jurnal Ners dan Kebidanan Indonesia, 1(2), 66-70.

Johar, W. E., Rejeki, S., \& Khayati, N. (2013). Persepsi dan Upaya Pencegahan Keputihan Pada Remaja Putri Di SMA Muhammadiyah 1 Semarang. Jurnal Keperawatan Maternitas, 1(1).

Loon, Y. K., Satari, M. H., \& Dewi, W. (2018). Antibacterial effect of pineapple (Ananas comosus) extract towards Staphylococcus aureus. Padjadjaran Journal of Dentistry, 30(1), 1-6.

Mokodongan, M. H., Wantania, J., \& Wagey, F. (2015). Hubungan Tingkat Pengetahuan Tentang Keputihan Dengan Perilaku Pencegahan Keputihan Pada Remaja Putri. e-CliniC, 3(1).

Notoatmodjo, S. 2010. Metodologi Penelitian Kesehatan. Jakarta: Rineka Cipta

Nurhidayah, Masriany, Masri M. (2013). Isolasi dan Pengukuran Aktivitas Enzim Bromelin dari Ekstrak Kasar Batang Nanas (Ananas comosus) Berdasarkan Variasi $\mathrm{pH}$. Biogenesis. vol 1(2): 116-122. https://doi.org/10.24252/bio.vli2.457.

Rahmawati, E. (2017). Gambaran Kesehatan Reproduksi Penyapu Jalanan Perempuan di Kota Balikpapan Tahun 2016. Mahakam Midwifery Journal (MMJ), 2(1), 07-22.

Riza, Y., Qariati, N. I., \& Asrinawaty, A. (2019). Hubungan Personal Hygiene dan
Penggunaan Kontrasepsi dengan Kejadian Keputihan Pada Wanita Usia Subur (WUS). MPPKI (Media Publikasi Promosi Kesehatan Indonesia): The Indonesian Journal of Health Promotion, 2(2), 69-74.

Rakhmanda, A. P. (2008). Perbandingan efek antibakteri jus nanas (ananas comosus L. merr) pada berbagai konsentrasi terhadap Streptococcus mutans. [Skripsi]. Semarang: Fakultas Kedokteran, Universitas Diponegoro.

Rismawan, W. (2017). Gambaran Tingkat Kecemasan Wanita Usia Subur 20-45 Tahun yang Mengalami Keputihan Di Rw 01 Kelurahan Setiajaya Kecamatan Cibeureum Kota Tasikmalaya. Jurnal Kesehatan Bakti Tunas Husada: Jurnal Ilmu-ilmu Keperawatan, Analis Kesehatan dan Farmasi, 17(1), 166-175

Sandriana, I. F. I., \& Rachman, W. A. (2014). Perilaku Personal Hygiene Genitalia Santriwati Di Pesantren UMmul Mukminin Makassar Sulawesi Selatan. Jurnal Kesehatan Masyarakat. Vol, 7, 22-23.

Suerni, E., Alwi, M., \& Guli, M. M. (2013). Uji Daya Hambat Ekstrak Buah Nanas (Ananas comosus L. Merr.), Salak (Salacca edulis Reinw.) dan Mangga Kweni (Mangifera odorata Griff.) terhadap Daya Hambat Staphylococcus aureus. Jurnal Biocelebes, 7(1), 35-47.

Umarudin, M. (2018). Efektivitas Daya Hambat Ekstrak Etanol 96\% Bonggol Nanas (Ananas Comosus L) Terhadap Pertumbuhan Bakteri Staphylococcus Aureus. Journal of Pharmacy and Science, 3(2).

Wiayanti. 2009. Fakta Penting Seputaran Kesehatan Reproduksi Wanita. Yogyakarta: Book Marks.

Wulaningtyas, E. S., \& Widyawati, E. (2018). Hubungan kejadian Flour Albus dengan tingkat kecemasan terhadap Infeksi Maternal pada WUS. Jurnal Ners dan Kebidanan (Journal of Ners and Midwifery), 5(2), 123-128.

Yuliasari, D., Sari, F. E., \& Astriani, R. (2015). Hubungan Personal Hygiene dengan Keputihan pada Remaja Putri di Risma Miftahul Huda Lampung Selatan Tahun 2015. Jurnal Kebidanan Malahayati, 1(3). 